\title{
DANUBE SPECIES VIVIPARUS ACEROSUS (BOURGUIGNAT, 1862) (GASTROPODA: VIVIPARIDAE) IN UKRAINE
}

\author{
ROMAN GURAL ${ }^{1 *}$, VASYL GLEBA ${ }^{2}$, NINA GURAL-SVERLOVA ${ }^{1}$ \\ ${ }^{1}$ State Museum of Natural History, National Academy of Sciences of Ukraine, Teatralna 18, 79008 Lviv, \\ Ukraine (e-mail: gural.roman@gmail.com, sverlova@pip-mollusca.org) \\ ${ }^{2}$ Ukrainian Society for the Protection of Birds, Chervonoarmiiska 148, 90332 Korolevo, Ukraine \\ (e-mail: glebasileus@mail.ru) \\ *corresponding author
}

\begin{abstract}
The Danube species Viviparus acerosus has been recorded for the first time from the Transcarpathian region of Ukraine. The material was collected in autumn 2018 on the bank of the Roman-Potik reservoir in the environs of Dunkovitsa village, Irshava district. The conchological peculiarities of the adult and embryonic specimens have been described and illustrated, and the shell sizes of the adults are given. It is possible that $V$. acerosus may occur in other localities of western and south-western parts of Ukraine, but has been mistaken for large specimens of the widespread species Viviparus viviparus. From the Lower Danube in the southwest of the Odessa region, $V$. acerosus was recorded for the first time as far back as the beginning of the 20th century. In the middle of the 20th century it might be mentioned from this territory as $V$. viviparus var. hungarica. The necessity for more thorough study of the species composition and distribution of representatives of the genus Viviparus in the Ukrainian part of the Danube basin is argued.
\end{abstract}

KEY WORDS: freshwater molluscs, Viviparus, Danube basin, Transcarpathian region, Ukraine

\section{INTRODUCTION}

Although the presence of the Danube species Viviparus acerosus (Bourguignat, 1862) in some areas of western and south-western Ukraine looks quite natural, the precise data on its findings in the Ukrainian part of the Danube basin are few. The literature references (LINDHOLM 1906, ZHADIN 1952, DZHURTUBAEV et al. 2017), which apparently concern the true $V$. acerosus, relate exclusively to the lower reaches of the Danube River in the southwest of the Odessa region. The analysis of the present distribution of $V$. acerosus in Ukraine is considerably complicated due to the significant differences in the interpretation of this species and some other European representatives of the genus Viviparus Montfort, 1810 by East European (CHERNOGORENKO 1988, ANISTRATENKO \& ANISTRATENKO 2001, StARobogatov et al. 2004) and Central European (GLÖER 2002, GLÖER \& GEORGIEV 2014) researchers.
Thus, in the Eastern European malacological literature $V$. acerosus has recently been mentioned from Ukraine exclusively as a junior synonym to Viviparus ater (Christofori et Jan, 1832) (ANISTRATENKO \& ANISTRATENKO 2001, KANTOR \& SYSOEV 2005, VINARSKI \& KANTOR 2016). However, the Central European malacologists recognise the validity of both species (FALNIOWSKI et al. 1996a, b, 1998, GLÖER 2002, GLÖER \& GEORGIEV 2014), which was further confirmed by recent molecular study (RYSIEWSKA et al. 2019). The occurrence in Ukraine of the Southern Alpine species V. ater (GLÖER 2002) also requires additional confirmation. It is quite possible that large specimens of Viviparus viviparus (Linnaeus, 1758) from Ukraine with a relatively narrow apical angle (ANISTRATENKO \& ANISTRATENKO 2001) have been taken for $V$. ater by mistake. 
Moreover, some researchers (ANDRIYCHUK 2015, GURAL \& GURAL-SVERLOVA 2018) considered until recently that only two representatives of the family Viviparidae with generally accepted species status have been reliably recorded from Ukraine: Viviparus contectus (Millet, 1813) and V. viviparus. Other researches mentioned the occurrence of 5 species (RYABCEVA 2013) and even 8 species (ANISTRATENKO \& ANISTRATENKO 2001), five of which being in fact forms of $V$. contectus. Two other taxa, $V$. ater and Viviparus sphaeridius (Bourguignat, 1880), the species status of which is now recognised by the Central European researchers (GLÖER \& GEORGIEV 2014) as well, are interpreted by the Ukrainian malacologists differently and in most cases may proved to be just

\section{MATERIAL AND METHODS}

The paper is based on the study of adult and juvenile (embryonic) specimens of $V$. acerosus, collected by VASYL GLEBA on the bank of the Roman-Potik reservoir (Fig. 1) in the vicinity of Dunkovitsa village, Irshava district, Transcarpathian region, near the highway Mukachevo-Khust. The coordinates of the collection point: $48^{\circ} 19^{\prime} 05.4^{\prime \prime} \mathrm{N}, 22^{\circ} 53^{\prime} 22.2^{\prime \prime} \mathrm{E}$.

The reservoir, located between Dunkovitsa and Gorbok villages, was formed by construction of a dam erected on a small river Roman (another name Roman-Potik). The reservoir is used now for fish breeding and recreation. A study has shown a satisfactory chemical composition of water and at the same time its strong bacteriological contamination (ROMAN 2017).

The first sample containing four empty shells of adult specimens of $V$. acerosus was taken on the bank of the reservoir in September 22, 2018, together with the shells of large bivalve molluscs Anodonta anatina (Linnaeus, 1758) and Unio tumidus Philipsson, 1788. The next sampling, containing several dozens of empty shells and snails that had recently died and also one living male (Fig. 2), was made in October 27, 2018. Embryonic specimens in different stages of development were extracted from bodies of eight dead females.

The height and width of the shells of adults were measured with a calliper with an accuracy of $0.1 \mathrm{~mm}$. the conchological forms of $V$. viviparus, what is described in more detail in Discussion.

In autumn 2018 several large shells of Viviparus from the Transcarpathian region of Ukraine were passed to the malacological collection of the State Museum of Natural History of the National Academy of Sciences of Ukraine (SMNH NASU) in Lviv, which we have preliminarily identified as $V$. acerosus. Repeated sampling in the same locality made it possible to extract from the bodies of females, recently died on the bank, above hundred embryonic shells, the study of which, following GLÖER \& GEORGIEV (2014), has further confirmed the correctness of the preliminary identification.

Other measurements were taken under a stereo microscope, using an ocular micrometer. The shells of adult individuals were measured according to the scheme shown in FALNIOWSKI et al. (1998: fig. 26). Whorl number in embryonic shells was counted according to the scheme in GLÖER (2002: fig. 16). The structure of embryonic shells and the surface sculpture on the shells of adults were observed under the binocular MBS-2. The material was identified by means of the keys, descriptions and pictures of adult and embryonic shells of Viviparus species distributed in Europe (GLÖER 2002, GLÖER \& GEORGIEV 2014).

For comparison, the material of the malacological collection of SMNH NASU was used (Figs 5-8), containing about 700 shells of Viviparus from the different regions of Ukraine: the basins of the Dnieper, Dniester, Southern and Western Bug, Seversky Donets (GURAL \& GURAL-SVERLOVA 2018). A special attention was paid to the large specimens of $V$. viviparus from the Kakhovka reservoir in the Dnieper, two of which are shown on Figs 6 \& 7. An embryonic shell from the same sample, collected in 2006 in the environs of Vasilevka town, Zaporozhye region (inventory number G936), is shown in Fig. 17. Both samples of $V$. acerosus from the Transcarpathian region, described in this paper, have been passed to the collection of freshwater molluscs of the same museum (inventory numbers G1564 and G1566).

\section{RESULTS}

The shells of $V$. acerosus (Figs 3, 4), collected in the Transcarpathian region, are greenish-horny, with three clearly visible spiral brownish bands. Whorls are relatively convex, but not stepped, as in $V$. contectus (Fig. 5). The umbilicus is covered to a considerable extent by the columellar margin of the aperture

(Figs 12, 13), thus acquiring a more or less slit-like shape. Sometimes this slit is so small (Fig. 13) that it can be clearly visible only if the aperture is turned slightly to the side.

In contrast to the conchologically similar species $V$. viviparus, the upper embryonic whorls in the shells 

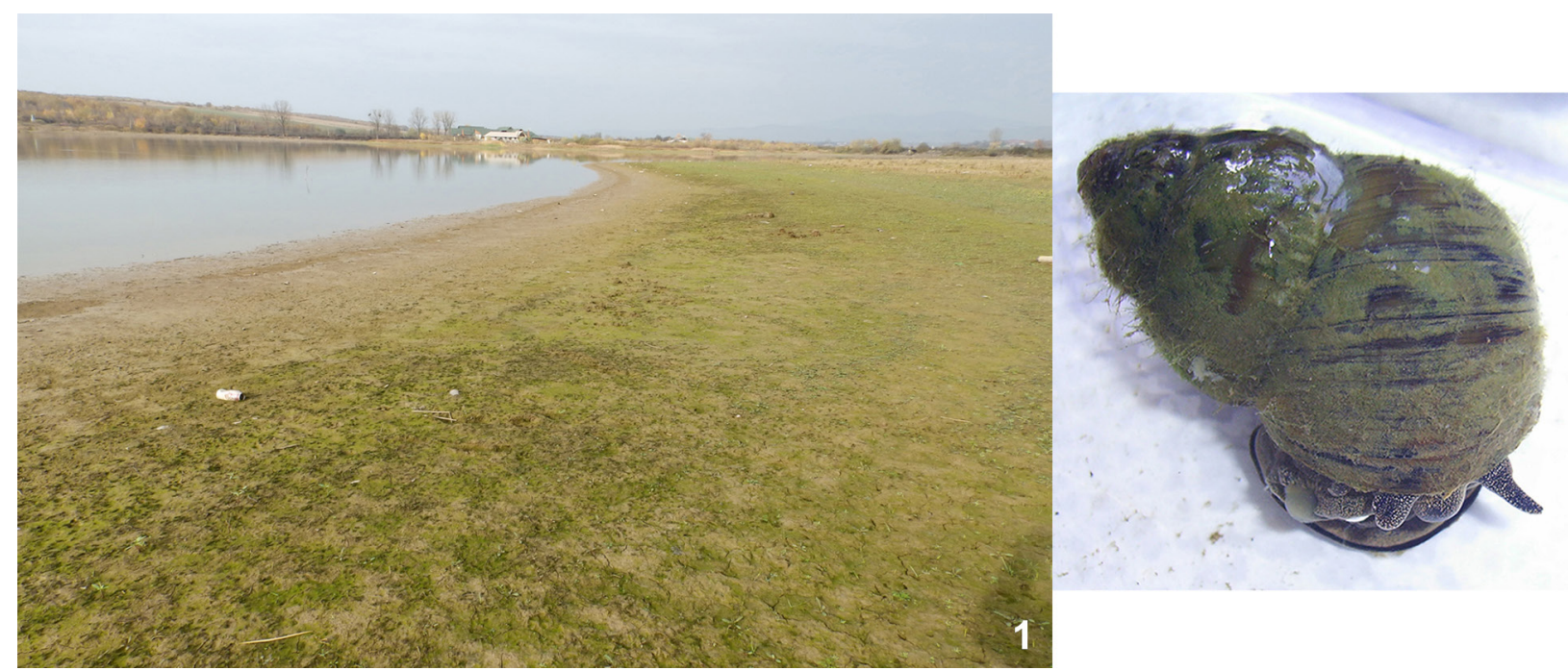

Figs 1, 2. Habitat of Viviparus acerosus in the Transcarpathian region (1) and alive male (2)
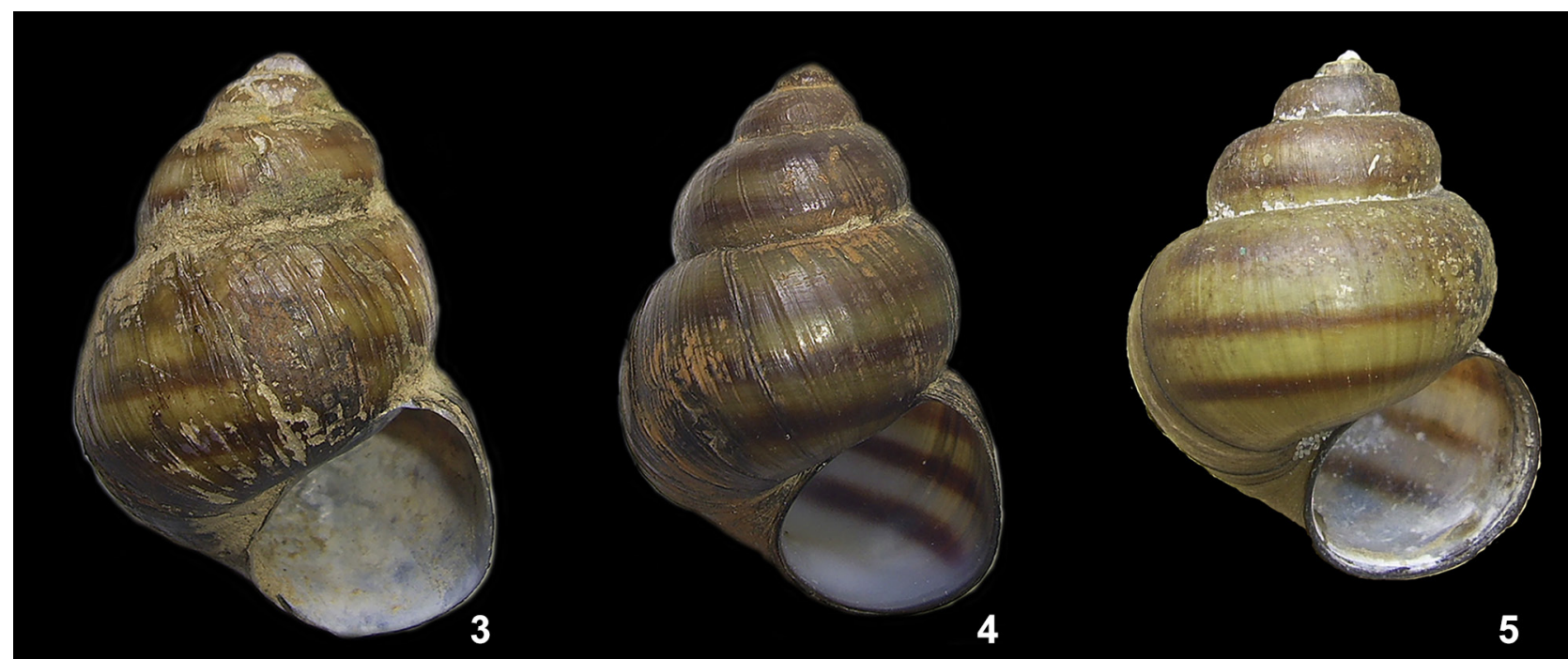

4
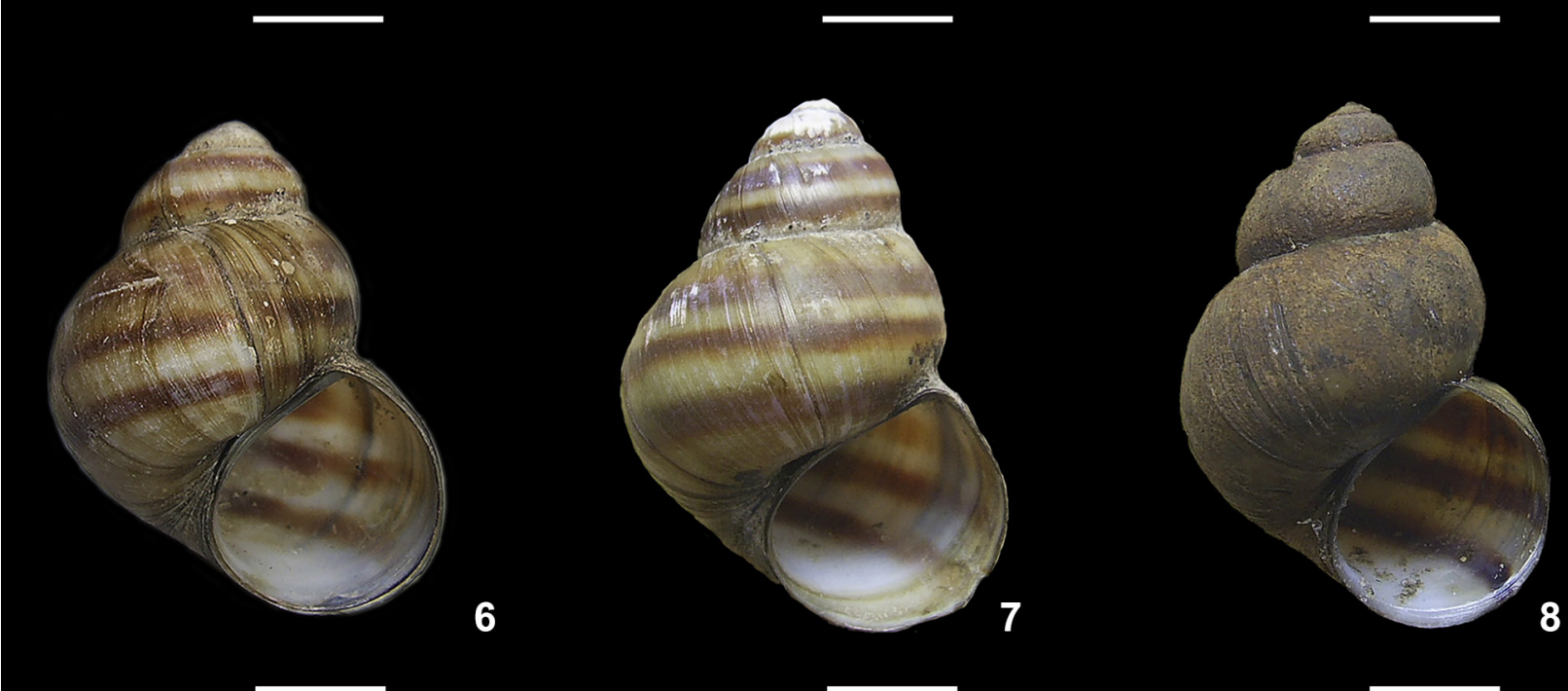

Figs 3-8. Shells of the adult specimens of Viviparus from Ukraine: 3, $4-V$. acerosus (4 - shell of the female), Dunkovitsa, Transcarpathian region; $5-$ V. contectus, Svityaz, Volyn region; 6, $7-$ V. viviparus, Vasilevka, Zaporozhye region; $8-V$. viviparus, Cherkassy, Cherkassy region. Scale bars $10 \mathrm{~mm}$ 
studied form an acute apex distinctly protruding upwards, which is typical of $V$. acerosus (GLÖER 2002). Since the apex in adults is corroded (Fig. 9), this character is much better expressed in the shells of embryonic specimens (Figs 15, 16).

The surface sculpture on the definitive whorls shows these features:

1. thin, intermittent, densely located radial wrinkles, well visible already at 10-20× magnification, which may be intersected with thinner, irregularly located wavy spiral wrinkles;

2. more coarse radial wrinkles;

3. chaotically located dents ("hammering" effect, malleate sculpture).

The sculptural elements of the second and third types, as a rule, one can see clearly even with the naked eye. The surface sculpture on the shells of $V$. viviparus from the Kakhovka reservoir in the Dnieper (Figs 6, 7), used for comparison, was in general similar to $V$. acerosus from the Transcarpathian region, but less expressed. In particular, the elements of the malleate sculpture were visible only on certain parts of the definitive whorls. It is possible, that such differ- ences, at least in part, might be conditioned by somewhat greater thickness of the shell walls in $V$. viviparus.

The embryonic shells (Figs 15, 16) are light horny, with three darker (brownish) spiral bands on the last whorl. Their periphery is slightly angular, and this angularity being more clearly expressed in smaller shells belonging to younger individuals (Fig. 16). The umbilicus is partially covered by the columellar margin of the aperture.

The surface of embryonic shells has thin, densely arranged spiral wrinkles (Fig. 18), straight or slightly wavy, already visible at $10 \times$ and clearly visible at $20 \times$ magnification. On the lower whorls in the largest specimens, the elements of the radial sculpture become visible, although less distinct then on the definitive whorls.

Some spiral wrinkles are covered with densely arranged hairs, and the length of the hairs being equal in one row and may differ significantly between rows. The longest hairs (Fig. 19) are arranged on the periphery of the whorls. The hairs of similar length are visible on the periphery of the shell of juvenile $V$. acerosus from Hungary, shown in GLÖER \& GEORGIEV

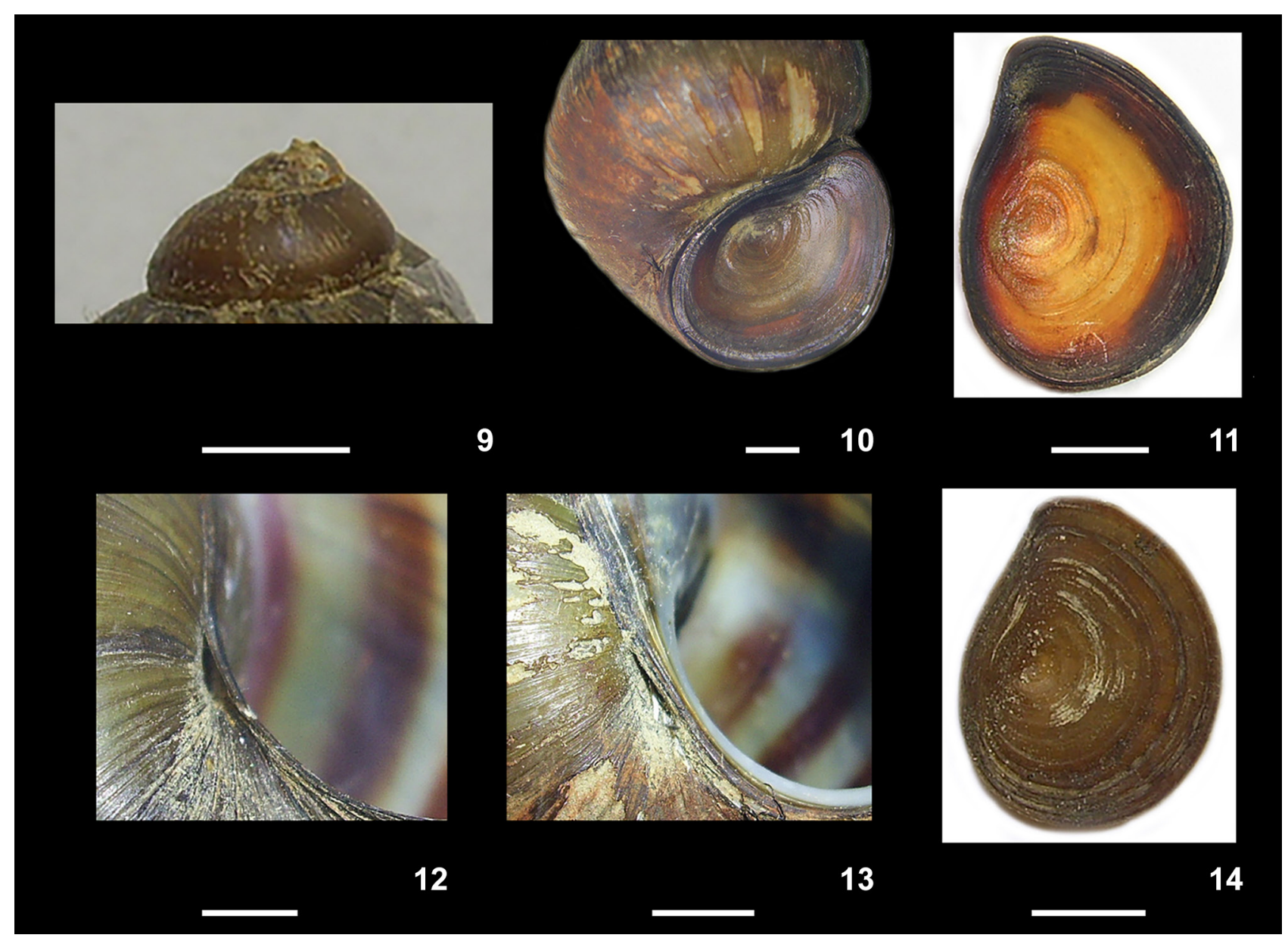

Figs 9-14. Shell fragments of the adult specimens of Viviparus: 9-13 - V. acerosus, Dunkovitsa, Transcarpathian region (9 corroded apex of the shell, 10 - last whorl with operculum in male, 11 - operculum, 12 - umbilicus of the female; 13 - umbilicus of the male); 14 - V. viviparus, Vasilevka, Zaporozhye region (operculum). Scale bars $5 \mathrm{~mm}$ 


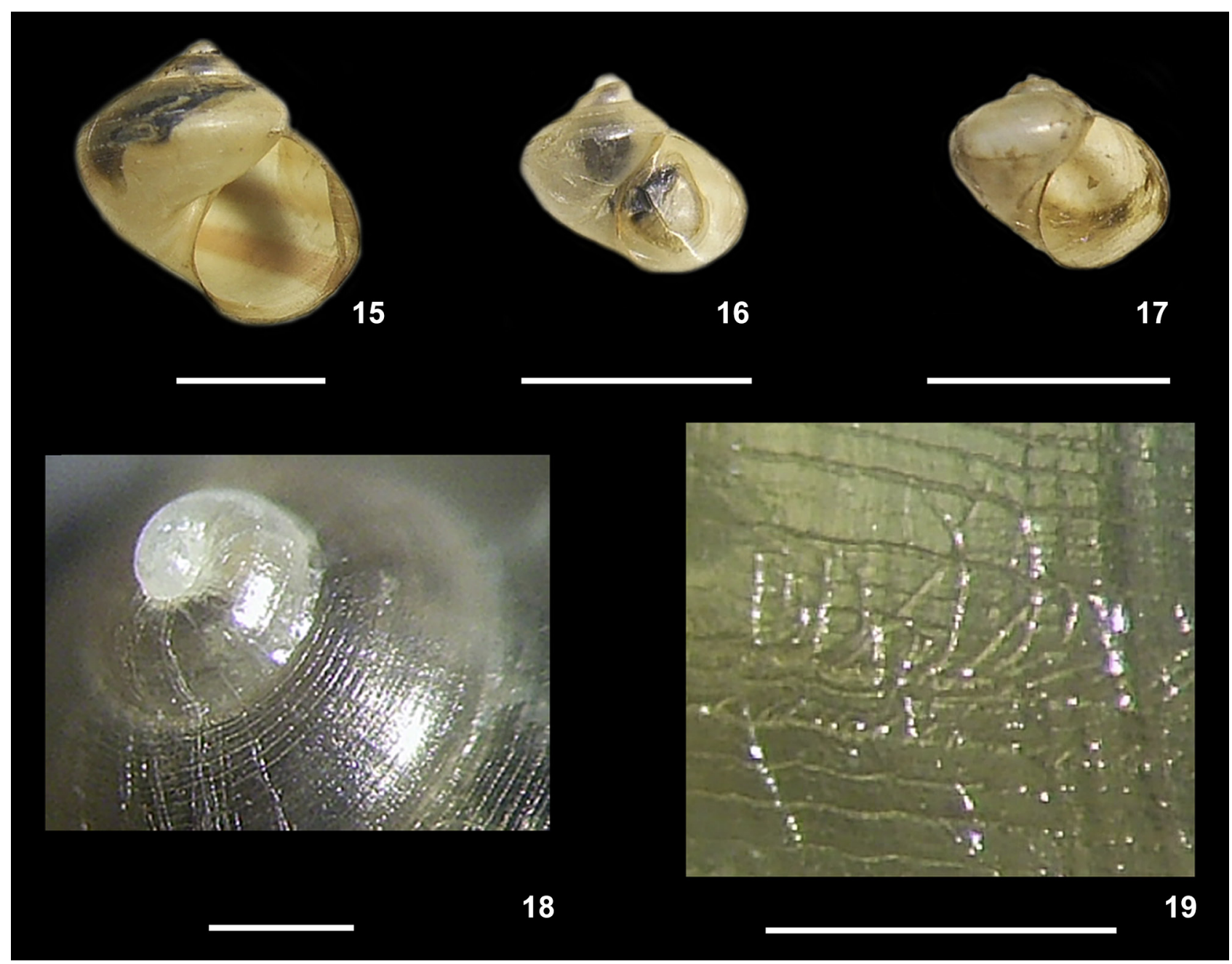

Figs 15-19. Shells of the embryonic specimens of Viviparus: 15, 16, 18, $19-$ V. acerosus, Dunkovitsa, Transcarpathian region; 17 - V. viviparus, Vasilevka, Zaporozhye region; 18 - shell apex and spiral sculpture of the surface; 19 - spiral wrinkles and hairs on the periphery of the last whorl. Scale bars $5 \mathrm{~mm}$ on Figs 15-17, $0.5 \mathrm{~mm}$ on Figs 18, 19

Table 1. Shell sizes of the adult specimens of $V$. acerosus from the Transcarpathian region

\begin{tabular}{|c|c|c|c|c|c|c|}
\hline \multirow{3}{*}{ Parameters, mm } & \multicolumn{6}{|c|}{ Categories } \\
\hline & \multirow{2}{*}{$\begin{array}{c}\text { Empty shells* } \\
(\mathrm{N}=22) \\
\mathrm{M} \pm \mathrm{m}\end{array}$} & \multirow{2}{*}{$\begin{array}{c}\text { Females }(\mathrm{N}=8) \\
\mathrm{M} \pm \mathrm{m}\end{array}$} & \multirow{2}{*}{$\begin{array}{c}\text { Male } \\
(\mathrm{N}=1)\end{array}$} & \multicolumn{3}{|c|}{$\begin{array}{c}\text { Total } \\
(\mathrm{N}=31)\end{array}$} \\
\hline & & & & $\mathrm{M} \pm \mathrm{m}$ & $\max$ & $\min$ \\
\hline Shell height & $44.0 \pm 0.58$ & $45.4 \pm 1.15$ & 46.0 & $44.4 \pm 0.51$ & 50.5 & 39.2 \\
\hline Shell width & $29.7 \pm 0.32$ & $30.6 \pm 0.61$ & 31.5 & $30.0 \pm 0.29$ & 33.9 & 27.5 \\
\hline Spire height & $10.7 \pm 0.31$ & $11.3 \pm 0.58$ & 10.7 & $10.8 \pm 0.27$ & 13.3 & 7.7 \\
\hline Aperture height & $18.4 \pm 0.20$ & $19.0 \pm 0.50$ & 18.3 & $18.6 \pm 0.19$ & 21.3 & 16.8 \\
\hline Aperture width & $16.8 \pm 0.21$ & $16.5 \pm 0.45$ & 17.8 & $16.8 \pm 0.19$ & 18.7 & 14.5 \\
\hline Antepenultimate whorl height & $2.7 \pm 0.07$ & $2.7 \pm 0.09$ & 2.7 & $2.7 \pm 0.06$ & 3.3 & 2.2 \\
\hline Antepenultimate whorl width & $9.4 \pm 0.20$ & $9.9 \pm 0.35$ & 9.8 & $9.5 \pm 0.17$ & 11.5 & 7.8 \\
\hline Penultimate whorl height & $6.4 \pm 0.16$ & $6.8 \pm 0.36$ & 6.0 & $6.5 \pm 0.14$ & 8.2 & 5.0 \\
\hline Penultimate whorl width & $17.0 \pm 0.28$ & $17.7 \pm 0.50$ & 17.7 & $17.2 \pm 0.24$ & 19.5 & 14.7 \\
\hline
\end{tabular}

Abbreviations: $\mathrm{M}$ - arithmetic average; $\mathrm{m}$ - arithmetic average error; max - maximum value of the parameter; min - minimum value, $\mathrm{N}$ - number of the shells measured, ${ }^{*}$ - sex of the molluscs is unknown. 
(2014: fig. 5E), and on the embryonic shell of this species from Slovakia (FALNIOWSKI et al. 1996b: figs $2,17)$.

The sizes of collected adult shells of $V$. acerosus are given in Table 1. The maximum height of the shell reached $50.5 \mathrm{~mm}$, the maximum width $-33.9 \mathrm{~mm}$ in one of the females. In the three largest embryonic shells kept in SMNH NASU with the whorls numbering from 3.2 to 3.6 shell height varies from 6.0 to $7.6 \mathrm{~mm}$, shell width from 6.3 to $7.5 \mathrm{~mm}$, aperture height from 4.3 to $4.9 \mathrm{~mm}$, aperture width from 3.7 to $4.3 \mathrm{~mm}$.

\section{DISCUSSION}

The large size and the acute apex of the shell, distinctly protruding upwards, that is best visible in embryonic specimens, make possible the clear differentiation of the specimens collected in the Transcarpathian region from $V$. viviparus, widely distributed in Ukraine. Among all Viviparus species occurring in Europe, only $V$. viviparus has a blunt apex (GLÖER \& GEORGIEV 2014).

It is somewhat more difficult to distinguish $V$. acerosus from another conchologically similar species $-V$. ater (GLÖER 2002, SOES et al. 2009). As usual, the differences in the growth rate of the two upper (embryonic) shell whorls in these two species, resulting in the shaping of a disproportionately small apex in $V$. acerosus (GLÖER 2002), have been mentioned. However, it is a problem to apply this character to the shells with corroded apex. In this case, much more reliable is the using of such a diagnostic character as the presence or absence of hairs on the shells of embryonic individuals and their relative length: in $V$. acerosus the embryonic shell is covered with hairs; in $V$. ater the hairs are absent or very small (GLÖER \& GEORGIEV 2014). According to FALNIOWSKI et al. (1996b), the main bristles in $V$. ater and $V$. acerosus are «moderately long». However, the scale of Fig. 16 (photograph of the surface of the last whorl of the embryonic shell in $V$. ater) and Fig. 17 (the same in $V$. acerosus) shows that they are at least twice as long in $A$. acerosus. Thus, according to the hair length, molluscs collected in the Transcarpathian region should be attributed to $V$. acerosus.

In our opinion, the use of another diagnostic character proposed by GLÖER \& GEORGIEV (2014) is not so straightforward: the presence of a weak cant on the periphery of the last whorl in juveniles of $V$. ater in comparison with the rounded whorl in $V$. acerosus. It is possible, that this character may be applied only to juvenile molluscs that have already left the body of the maternal individual and to the older embryonic specimens. As our study has shown, in younger embryonic specimens of $V$. acerosus with smaller shells, the periphery of the last whorl also looks more or less angular (Fig. 16), what can lead to an erroneous identification. One can also see small angularity in the shell photos of juvenile (embryonic) individuals of $V$. acerosus from other parts of the species range (FALNIOWSKI et al. 1996b: fig. 2, GLÖER \& MEIERBROOK 1998, GLÖER 2002: fig. 40).
$V$. acerosus has recently been often mentioned mistakenly from Ukraine as a junior synonym to $V$. ater (ANISTRATENKO \& ANISTRATENKO 2001, KANTOR \& SYSOEV 2005, VINARSKI \& KANTOR 2016). The reason for this was the publication of CHERNOGORENKO (1988), who has reviewed the Viviparidae species composition of Europe and Western Asia. Having compared the image of Viviparus mamillatus (Küster, 1852) from Montenegro in the original description of this species (KÜSTER 1852) with the large Viviparus shells from Hungary and the Northern Black Sea Coast, which she has identified as V. acerosus, this researcher came to the conclusion that they are "completely identical in all Raup's parameters".

However Central European malacologists either recognise the validity of all three species: $V$. acerosus, V. ater and V. mamillatus (GLÖER 2002, WELTERSCHULTES 2012), or consider V. mamillatus a junior synonym of $V$. contectus (RYSIEWSKA et al. 2019). Moreover, the distribution areas of $V$. ater and $V$. mamillatus, known at present, do not coincide (WELTER-SCHULTES 2012). V. ater does not occur in Montenegro, where the material described by KÜSTER (1852: 9, taf. 2, fig. 1-5) was collected. Therefore, the images of $V$. mamillatus presented by KÜSTER (1852), in any way could not be the reason for bringing $V$. acerosus in synonymy with $V$. ater. It has also been shown that $V$. acerosus and $V$. ater can be clearly differentiated by the structure of embryonic shells (GLÖER \& GEORGIEV 2014), as has been mentioned above.

Besides, the occurrence of a Southern Alpine species V. ater (GLÖER 2002) in Ukraine in itself remains unproven, and needs additional confirmation, taking into account the diagnostic characters used by the Central European malacologists (GLÖER 2002, GLÖER \& GEORGIEV 2014). According to these researches, within its natural range $V$. ater is distributed in Northern Italy (GLÖER 2002, WELTER-SCHULTES 2012), from where it has been brought by the human to some lakes in Switzerland (Geneva, Zurich) and later on - to the Lake Constance (Bodensee) (GLÖER 2002, WELTER-SCHULTES 2012). Moreover, this species was introduced to France (GARGOMINY et al. 2011). Eastwards from Northern Italy, $V$. ater has been found in Croatia and Slovenia, where it is represented by the subspecies $V$. ater gallensteini (Kobelt, 1892) (VAVRova 2010). The reference to 
the isolated occurrence of $V$. ater in Central Greece (WELTER-SCHULTES 2012) concerns Viviparus hellenicus (Clessin, 1879), which previously has been considered as subspecies of $V$. ater (VAVROVA 2010), and at present - as a separate species (FALNIOWSKI et al. 1996b, GLÖER \& GEORGIEV 2014). Taking into consideration the general picture of $V$. ater distribution, it should be noted, that although some finds of this species in the territory of Ukraine may be possible, they must be associated with anthropochory.

The Eastern European malacologists (ANISTRATENKO \& ANISTRATENKO 2001, STAROBOGATOV et al. 2004), following CHERNOGORENKO (1988), consider that the natural range of $V$. ater is much broader and includes the entire Danube basin and the Northern Black Sea coast as well. In the opinion of these authors, $V$. ater in Ukraine has been distributed in the Danube, Dniester and Dnieper basins. They consider that this species earlier occurred downstream the Dnieper rapids and in the right tributaries of the Prypiat, and later on has spread over the whole Dnieper owing to the regulation of its flow by the complex of reservoirs (ANISTRATENKO \& ANISTRATENKO 2001). However, it is possible that in that region the large specimens of $V$. viviparus for a long time have been accepted as $V$. ater on the grounds of «a faster increase in the cross-section of the shell tube» (CHERNOGORENKO 1988), resulting in a slightly larger width of the last whorl (ANISTRATENKO \& ANISTRATENKO 2001). Slight differences in the size of the apical angle were also mentioned, in $V$. viviparus usually making up about $105-108^{\circ}$, and in $V$. ater, in the opinion of the Eastern European malacologists, not more than $100^{\circ}$ (ANISTRATENKO \& ANISTRATENKO 2001).

Unfortunately, none of the descriptions of $V$. ater or the identification keys of Viviparus species, com- piled by the authors mentioned above, contains the conchological character that has been used for differentiation of $V$. viviparus and other European Viviparus species by Central European malacologists (GLÖER 2002, GLÖER \& GEORGIEV 2014). This is an acute apex of the shell, distinctly protruding upwards in $V$. ater and other species in comparison with a blunt, smoothed apex in $V$. viviparus.

According to ANISTRATENKO \& ANISTRATENKO (2001), the maximum shell sizes of $V$. ater and $V$. viviparus are the same: the height of the shell $40 \mathrm{~mm}$ and its width $30 \mathrm{~mm}$. This also made us think about the possibility of the erroneous identification, since both $V$. ater, and especially $V$. acerosus, which these authors have proposed as a synonym to the former species (see above), are characterised by larger shells in comparison with $V$. viviparus (GLÖER \& MEIERBROOK 1998, GLÖER 2002, WelTER-SCHULTES 2012).

CHERNOGORENKO (1988) has not mentioned the dimensional parameters of molluscs from the territory of Ukraine, which were recognised by herself as $V$. ater. This author's paper includes a drawing of one shell from the Kiev reservoir (Fig. 20), reproduced later in the works of ANISTRATENKO (ANISTRATENKO \& ANISTRATENKO 2001, etc.). Judging by the scale bar, the height of this shell is about $36 \mathrm{~mm}$, and its shape is more similar to V. viviparus (Fig. 7) than to $V$. ater. A completely different image of the $V$. ater shell (Fig. 21), adopted from the work of KOBELT (1909), is given in the guide of STAROBOGATOV et al. (2004). Obviously, it is a slightly modified drawing of Vivipara pyramidalis erjaveci Kobelt, 1909 from a lake near Gorizia city, Italy (in German Görz) (KoBELT 1909: pl. 68, fig. 5) and bears no relation to Ukraine.

Two large samples of Viviparus from the Kakhovka reservoir in the Dnieper, collected in 2006 and 2017 and being kept in SMNH NASU (GURAL \& GURAL-
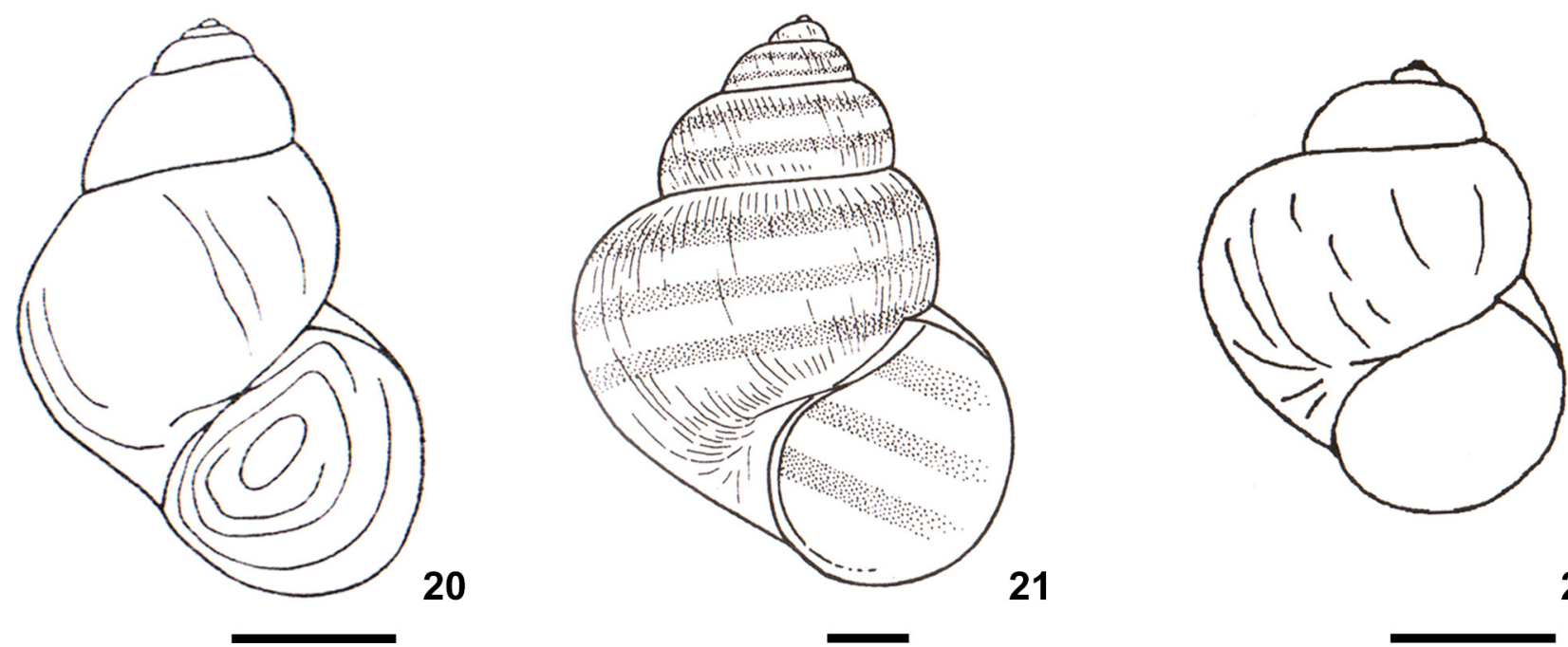

Figs 20-22. Pictures of the shells, determined as V. ater $(20,21)$ and $V$. sphaeridius (22), in publications of Eastern European malacologists: 20 - after CHERNOGORENKO (1988), 21 - after STAROBOGATOV et al. (2004), 22 - after ANISTRATENKO \& ANISTRATENKO (2001). Scale bars $10 \mathrm{~mm}$ 
SVERLOVA 2018), contain only V. viviparus shells, though these are relatively large for this species. The blunt apexes typical of this species and well preserved (non-corroded) even in adults, leave no doubt as to the correctness of the species identification. Two of the largest shells are shown on Figs 6,7 , and the shell of the embryonic individual - on Fig. 17. The maximum height of $V$. viviparus shells collected in the reservoir in 2006 is $42.1 \mathrm{~mm}$, in 2017 $-38.8 \mathrm{~mm}$, which is larger than the shell depicted in CHERNOGORENKO (1988). According to the monograph of ANISTRATENKO \& ANISTRATENKO (2001), in the lower Dnieper, in the Kakhovka and Zaporozhye reservoirs, $V$. ater predominates among the Viviparus species.

It is also possible that in Ukraine by the name $V$. ater a mixture of two species has been recently designated: certain conchological forms of $V$. viviparus (in particular, from the above-mentioned Dnieper reservoirs) and $V$. acerosus (from the lower Danube - see below). It is significant that in the thesis by RYABCEVA (2013: fig. 1) only two locations of V. ater have been mentioned: several closely situated localities in the lower reaches of the Danube and one locality in the Kiev region. Obviously, in the latter case the question is about a fish-breeding pond in Nemeshaevo village, where the large specimens of Viviparus have been found with a shell height up to $44.3 \mathrm{~mm}$ (RYABCEVA \& DEGTYARENKO 2011). If these authors were not dealing with an abnormally large form of $V$. viviparus, the colony they have investigated could be formed as a result of anthropochory, for example, by individuals transferred from the Danube basin.

From the lower Danube in the south-west of the modern Odessa region, $V$. acerosus was recorded for the first time at the beginning of the 20th century by the material from Lake Cahul in the environs of Reni, collected in 1903 by Alexander Brauner (LINDHOLM 1908). Despite the relatively small size of adults (shell height from 40 to $42 \mathrm{~mm}$ at 6.5 whorls) for $V$. acerosus, the molluscs collected in Cahul obviously could not belong to V. viviparus. LINDHOLM (1908) has emphasised such a distinctive character of $V$. acerosus as "vorragender, fast nadelspitzer Apex" (protruding, sharp apex, almost like a needle).

The subsequent indication of possible availability of true $V$. acerosus in the territory of Ukraine can be found in the monograph of ZHADIN (1952), who mentioned the large form of $V$. viviparus with shell height up to $57 \mathrm{~mm}$ and width up to $40 \mathrm{~mm}$, which occurred in the oxbows of the Danube. Such large specimens of Viviparus have been mentioned from the hydrotopes of the Danube delta recently as well (DZHURTUBAEV et al. 2017). The name V. viviparus var. hungaricus Hazay, 1881, used by ZHADIN (1952), is usually considered as a synonym to $V$. acerosus
(GLÖER 2002), although CHERNOGORENKO (1988) proposed to allocate $V$. hungaricus into a separate subgenus Hazayipaludina Tchernogorenko et Starobogatov, 1988, which is characterised by more thin-walled shell with a well-developed malleate sculpture on its surface. She has, however, also brought $V$. hungaricus to a synonymy not with $V$. acerosus, but with $V$. rossmaessleri (Bourguignat, 1880) and with $V$. pyramydalis Rossmässler, 1835 . Both $V$. pyramydalis (GLÖER 2002, VAVROVA 2010), and V. rossmaessleri (VAVROVA 2010) are now considered as junior synonyms of $V$. ater. The same researcher (CHERNOGORENKO 1988) suggested that $V$. rossmaessleri (in her own conception of this taxon, and not as a synonym to $V$. ater) in future could be found in the hydrotopes of the Transcarpathian region of Ukraine. Obviously, this assumption should be also attributed to the Danube species $V$. acerosus.

Since the true $V$. acerosus is distributed in the Danube basin (GLÖER 2002, WELTER-SCHULTES 2012), in Ukraine it may occur in the lower reaches of this river (the south-western outskirts of the Odessa region, as indicated in the above-mentioned literature), in the basins of the Tysa (Transcarpathian region, where this species has been found by the authors of this paper) and the Prut rivers (Chernovtsy region and the southern part of Ivano-Frankovsk region). However, in order to establish the exact limits of the present distribution of this species in Ukraine, additional field and laboratory studies are necessary, desirably with the extraction and subsequent study of the embryonic specimens' shells (GLÖER \& GEORGIEV 2014). The study of the distribution and state of populations of $V$. acerosus in Ukraine is of particular importance because the north-eastern limit of the species range passes through this area (WELTERSCHULTES 2012), which can make $V$. acerosus here vulnerable enough. It should be noted that in the north-western edge of its range $V$. acerosus has been protected in Austria, Czech Republic and Germany (GLÖER 2002). In the latter case, the question is about isolated populations of this species in southern Germany near Passau and Geislingen (WELTERSCHULTES 2012).

The need of a more careful study of the Viviparus species composition in the Ukrainian part of the Danube basin is also connected with the recent redescription of $V$. sphaeridius, locus typicus of which is in the Danube on the present border between Romania and Bulgaria (GLÖER \& GEORGIEV 2014: fig. $1)$. The shell photos of adult and embryonic specimens of this species given by GLÖER \& GEORGIEV (2014: fig. 3) considerably differ from the images of $V$. sphaeridius in the publications of Ukrainian malacologists (ANISTRATENKO \& ANISTRATENKO 2001: fig. 84, RYABCEVA \& ANISTRATENKO 2012: figs 4E, 4F, RYABCEVA 2014: figs 2C, 2D). The differences in 
the shell outlines of adults are shown on Figs 23-26. The specimens from Ukraine (Figs 22, 25, 26) differ by more convex whorls, "distinctly rounded on the periphery" (ANISTRATENKO \& ANISTRATENKO 2001). The difference is especially noticeable on the last whorl, which in type specimens of $V$. sphaeridius looks rather slightly pressed in its upper half. The outline drawing of the shell in the guide by STAROBOGATOV et al. (2001) is much more similar to the type material of V. sphaeridius (GLÖER \& GEORGIEV 2014: fig. 3 ), but the origin of the depicted shell has not been indicated.

The outlines of the upper part of the embryonic shells in $V$. viviparus and $V$. sphaeridius from Ukraine in the paper by RYABCEVA \& ANISTRATENKO (2012: figs 4A, 4E) are similar and conform to those of $V$. viviparus, but not of $V$. sphaeridius from the locus typicus (GLÖER \& GEORGIEV 2014: fig. 5). This fact suggests Ukrainian researchers hitherto have dealt not with the true $V$. sphaeridius, which occurs in the Danube basin, but, most likely, with a conchological form of $V$. viviparus. At the same time, one cannot exclude the possibility of finding the true $V$. sphaeridius in the Ukrainian part of the Danube basin (first of all, in the lower reaches of the Danube in the territory of Odessa region). So far, in the territory of Ukraine, 3 species of Viviparidae can be considered as reliably registered: $V$. contectus, $V$. viviparus and $V$. acerosus. The schemes of their distribution (Figs 27, 28) were compiled by us on the basis of our own observations, collection material of SMNH NASU and literary data (ANISTRATENKO et al. 2014, GURAL \& GURAL-SVERLOVA 2018 and others).

Since the cases of successful introduction into other European countries are known both in $V$. acerosus (SOES et al. 2009) and true V. ater (GLÖER 2002, GARGOMINY et al. 2011, WELTER-SCHULTES 2012), it is necessary to check carefully all findings of Viviparus with especially large shells with height above 40 $\mathrm{mm}$, in different parts of Ukraine, as, for example, the finding from Nemeshaevo village, Kiev region (RYABCEVA \& DEGTYARENKO 2011). According to the literature, the shell height in true $V$. ater can reach $45 \mathrm{~mm}$ (GLÖER 2002, WELTER-SCHULTES 2012), in true $V$. acerosus - up to $50 \mathrm{~mm}$ (WELTER-SCHULTES 2012) and even more - up to $57 \mathrm{~mm}$ (GLÖER 2002). In the conchologically similar $V$. viviparus, widespread in Europe (WELTER-SCHULTES 2012) and in Ukraine (GURAL \& GURAL-SVERLOVA 2018), shell height usually does not exceed $40 \mathrm{~mm}$ (ZHADIN 1952, ANISTRATENKO \& ANISTRATENKO 2001, GLÖER 2002).

Thus our research has confirmed the presence of true $V$. acerosus in the territory of Ukraine, the natural range of which is restricted to the Danube basin. It is necessary to study Viviparus more thoroughly in the west (Transcarpathian, Ivano-Frankovsk and Chernovtsy regions) and the south-west (Odessa region) of the country in order to determine the exact distribution of $V$. acerosus and assess the state of its populations. Only with more precise and reliable data will it be possible to assess the need for conservation at regional or national levels. It is possible that further study of Viviparus species in the lower reaches of the Danube (Odessa region) would ascertain the presence or absence of another Danube species, $V$. sphaeridius, where present Ukrainian records may be in error.

\section{ACKNOWLEDGEMENTS}

Our greatest thanks go to IREN KonOvalOVA (State Museum of Natural History, Lviv) for help in translating the manuscript into English and for adjustment of the English text.
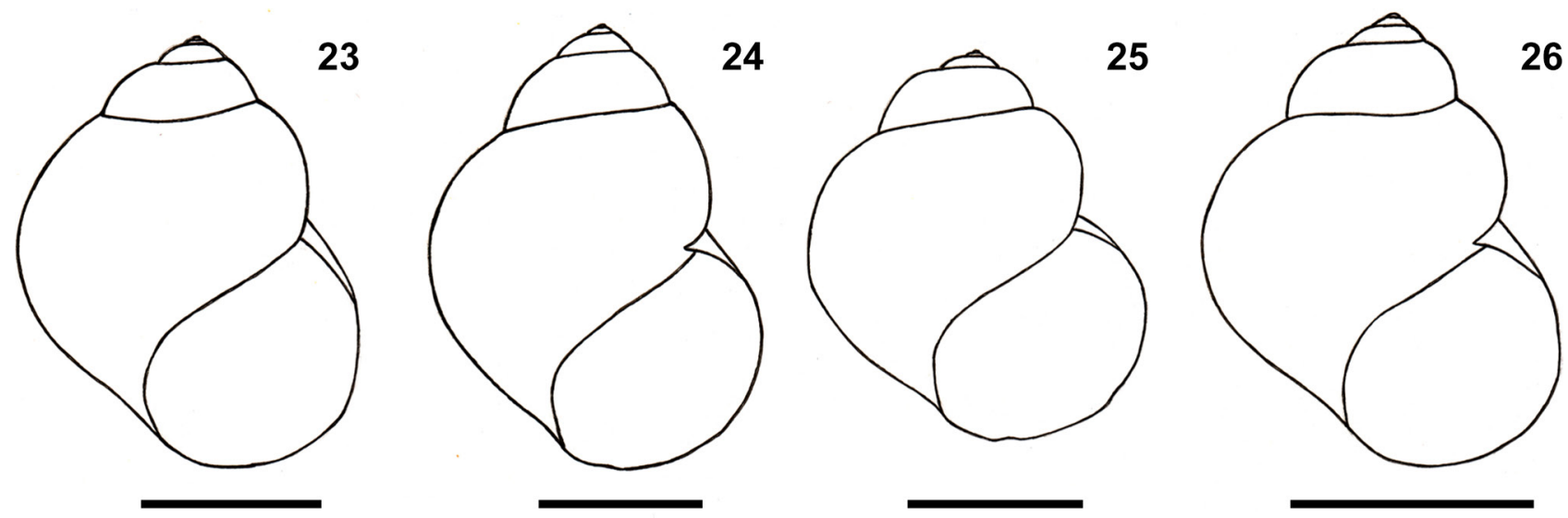

Figs 23-26. Outline drawings, made from photographs of the shells of $V$. sphaeridius in the publications of different authors: 23 - syntype (GLÖER \& GEORGIEV 2014: fig. 3A); 24 - topotype (GLÖER \& GEORGIEV 2014: fig. 3C); 25 - shell from the lower reaches of the Southern Bug (RYABCEVA 2014: fig. 2C); 26 - shell from the Dnieper basin (RYABCEVA 2014: fig. 2D). Scale bars $10 \mathrm{~mm}$ 


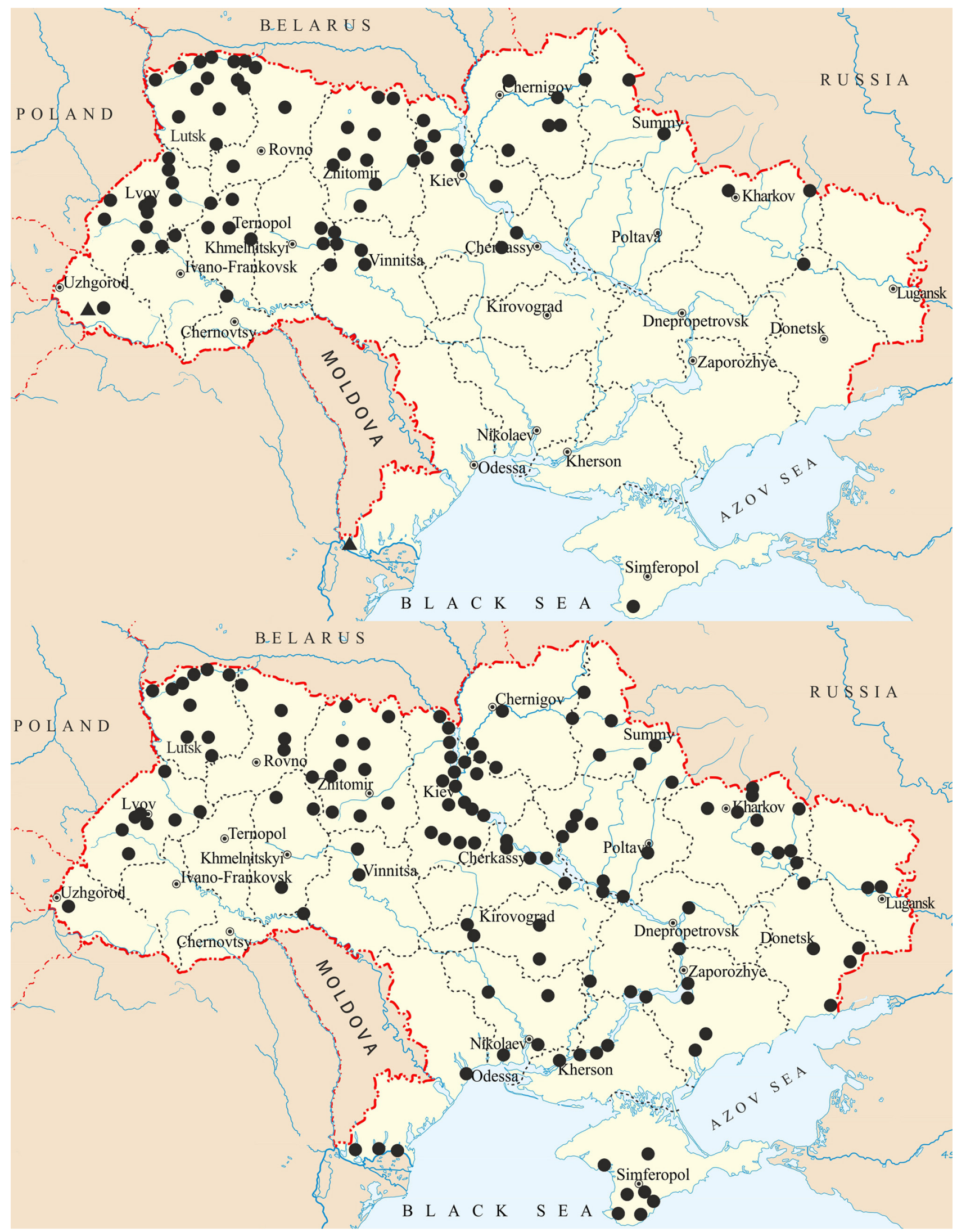

Figs 27-28. Locations of the finds of Viviparus species in Ukraine: 27 - V. contectus (circles) and V. acerosus (triangles); 28 V. viviparus 


\section{REFERENCES}

ANDRIYCHUK T. V. 2015. Minlyvist ta stateva struktura dvokh vydiv kaliuzhnyts Viviparus viviparus (Linnaeus, 1758) i Viviparus contectus (Millet, 1813) (Gastropoda, Viviparidae) u mezhakh Ukrainy: porivnialnyi analiz. Dissertation for a Candidate Degree in Biology. I. I. Schmalhausen Institute of Zoology, Kiev.

ANISTRATENKO V. V., ANISTRATENKO O. YU. 2001. Klass Pantsirnyie ili Hitonyi, klass Bryuhonogie Cyclobranchia, Scutibranchia i Pectinibranchia (chast). In: Fauna Ukrainyi. Mollyuski. Vol. 29(1). Veles, Kiev, pp. 1-240.

ANistratenko V. V., Degtyarenko E. V., ANistratenKO O. YU., PROZOROVA L. A. 2014. Modern distribution of gastropod mollusks of the family Viviparidae (Caenogastropoda) in continental water bodies of Eurasia. Biology Bulletin 41: 742-751.

CHERNOGORENKO E. W. 1988. O vidovom sostave viviparid (Gastropoda, Viviparidae) Evropyi i Zapadnoy Azii. Zoologichesky Zhurnal 67: 645-655.

DZHuRTUbaeV Yu. M., DZHURTUbaeV M. M., ZAMOROV V. V. 2017. Makrozoobentos pridunayskogo ozera Kagul (Odesskaya oblast, Ukraina). Ukrainian Journal of Ecology 7: 56-63. https://doi.org/10.15421/2017_49

FALNIOWSKI A., FIAŁKOWSKI W., SZAROWSKA M., MAZAN K. 1998. Shell biometry characters in species discrimination and classification within the genus Viviparus (Gastropoda: Architaenioglossa: Viviparidae). Malakologische Abhandlungen, Staatliches Museum für Tierkunde Dresden 19: 29-45.

FALNIOWSKI A., KOZIK A., SZAROWSKA M., FIAŁKOWSKI W., MAZAN K. 1996a. Allozyme and morphology evolution in European Viviparidae (Mollusca: Gastropoda: Architaenioglossa). Journal of Zoological Systematic and Evolutionary Research 34: 49-62.

FALNIOWSKI A., SZAROWSKA M., MAZAN K. 1996b. Embryonic shells of Viviparus - what they may tell us about taxonomy and phylogeny? (Gastropoda: Architaenioglossa: Viviparidae). Malakologische Abhandlungen, Staatliches Museum für Tierkunde Dresden 18: 35-42.

Gargominy O., Prie V., Bichain J.-M., Cucherat X., FONTAINE B. 2011. Liste de référence annotée des mollusques continentaux de France. MalaCo 7: 307-382.

GLÖER P. 2002. Süßwassergastropoden Nord- und Mitteleuropas. Bestimmungsschlüssel, Lebensweise, Verbreitung. In: Die Tierwelt Deutschlands und der angrenzenden Meeresteile nach ihren Merkmalen und nach ihrer Lebensweise. Vol. 73. ConchBooks, Hackenheim.

GLÖER P., GEORGIEV D. 2014. Redescription of Viviparus sphaeridius Bourguignat, 1880 with a identification key of European Viviparus species (Gastropoda: Viviparidae). Ecologica Montenegrina 1: 96-102.

GLÖER P., MEIER-BROOK C. 1998. Süsswassermollusken. Ein Bestimmungsschlüssel für die Bundesrepublik Deutschland. 12. Auflage. Deutscher Jugendbund für Naturbeobachtung, Hamburg.
GuRAl R. I., GURAL-SVERLOVA N. V. 2018. Kataloh prisnovodnykh moliuskiv Ukrainy. State Museum of Natural History, Lviv.

KANTOR Yu. I., SysOeV A. V. 2005. Katalog mollyuskov Rossii i sopredelnyih stran. Partnership of scientific publications KMK, Moscow.

Kobelt W. 1909. Die Gattung Paludina Lam. (Vivipara Mont.). Neue Folge. In Abbildungen nach der Natur mit Beschreibungen. In: Systematisches ConchylienCabinet von Martini und Chemnitz. Vol. 1(21a). Bauer \& Raspe, Nürnberg, pp. 97-430.

KÜSTER H. C. 1852. Die Gattungen Paludina, Hydrocaena und Valvata. In Abbildungen nach der Natur mit Beschreibungen. In: Systematisches ConchylienCabinet von Martini und Chemnitz. Vol. 1(21). Bauer \& Raspe, Nürnberg, pp. 1-96.

LiNDHOLM W. A. 1908. Materialien zur Molluskenfauna von Südwestrussland, Polen und der Krim. Notes of the Novorossiysk Society of Naturalists 31: 199-232.

ROMAN L. YU. 2017. Otsinka yakosti vod vodoskhovyshcha «Roman-Potik» sela Horbok Irshavskoho raionu Zakarpattia. Science Bulletin of Uzhgorod University. Series Chemistry 1(37): 99-105.

RYABCEVA YU. S. 2013. Cherevonohi moliusky rodyny Viviparidae Gray, 1847 Yevropy (porivnialna morfolohiia ta osoblyvosti biolohii). Thesis for a Candidate Degree in Biology. I. I. Schmalhausen Institute of Zoology, Kiev.

RYABCEVA YU. S. 2014. Vnutrividovaya izmenchivost rakovinyi bryuhonogih mollyuskov roda Viviparus v vodoymah Ukrainyi. Cherkasy University Bulletin: Biological Sciences Series 2: 93-99.

RYABCEVA YU. S., ANISTRATENKO V. V. 2012. Morfologicheskie osobennosti embrionalnoy rakovinyi mollyuskov roda Viviparus (Gastropoda, Viviparidae): popyitka razgranicheniya blizkih vidov, obitayuschih $\mathrm{v}$ Ukraine. The Bulletin of the Russian Far East Malacological Society 15/16: 117-128.

RYABCEVA YU. S., DEGTYARENKO E. V. 2011. Neobyichayno krupnyie zhivorodki (Gastropoda, Viviparidae) iz pruda pgt Nemeshaevo (Kievskaya oblast). Vestnik Zoologii 45(2): 160.

RYSIEWSKA A., HOFMAN S., OSIKOWSKI A., BERAN L., PEŠIĆ V., FALNIOWSKI A. 2019. Viviparus mamillatus (Küster, 1852), and partial congruence between the morphology-, allozyme- and DNA-based phylogeny in European Viviparidae (Caenogastropoda: Architaenioglossa). Folia Malacologica 27: 43-51. https://doi.org/10.12657/folmal.027.004

Soes D. M., GLÖER P., WINTER A. J. DE 2009. Viviparus acerosus (Bourguignat, 1862) (Gastropoda: Viviparidae), a new exotic snail species for the Dutch fauna. Aquatic Invasions 4: 373-375. https://doi.org/10.3391/ ai.2009.4.2.12

Starobogatov Ya. I., Prozorova L. A., Bogatov V. V., SAENKO E. M. 2004. Mollyuski. In: TSALOLIKHIN S. YA. (ed.) Opredelitel presnovodnyih bespozvonochnyih Rossii i sopredelnyih territoriy Vol. 6. Mollyuski, 
Polihetyi, Nemertinyi. Nauka, Saint-Petersburg, pp. 9-491.

VAVROVA L. 2010. Viviparus ater. The IUCN Red List of Threatened Species 2010. Available online at http://dx.doi.org/10.2305/IUCN.UK.2010-4.RLTS. T155859A4856421.en (accessed on 3 December 2018).

VINARSKI M. V., KANTOR Y. I. 2016. Analytical catalogue of fresh- and brackishwater mollusks of Russia and adjacent countries. KMK Scientific Press, Moscow.
WELTER-SCHULTES F. 2012. European non-marine molluscs, a guide for species identification. Planet Poster Editions, Göttingen.

ZHADIN V. I. 1952. Mollyuski presnyih i solonovatyih vod SSSR. In: Opredeliteli po faune SSSR, izdavaemyie Zoologicheskim institutom AN SSSR. Vol. 46. Publisher AS USSR, Moscow-Leningrad, pp. 1-376.

Received: February 2nd, 2019 Revised: July 22nd/25th, 2019

Accepted: August 4th, 2019 Published on-line: September 14th, 2019 